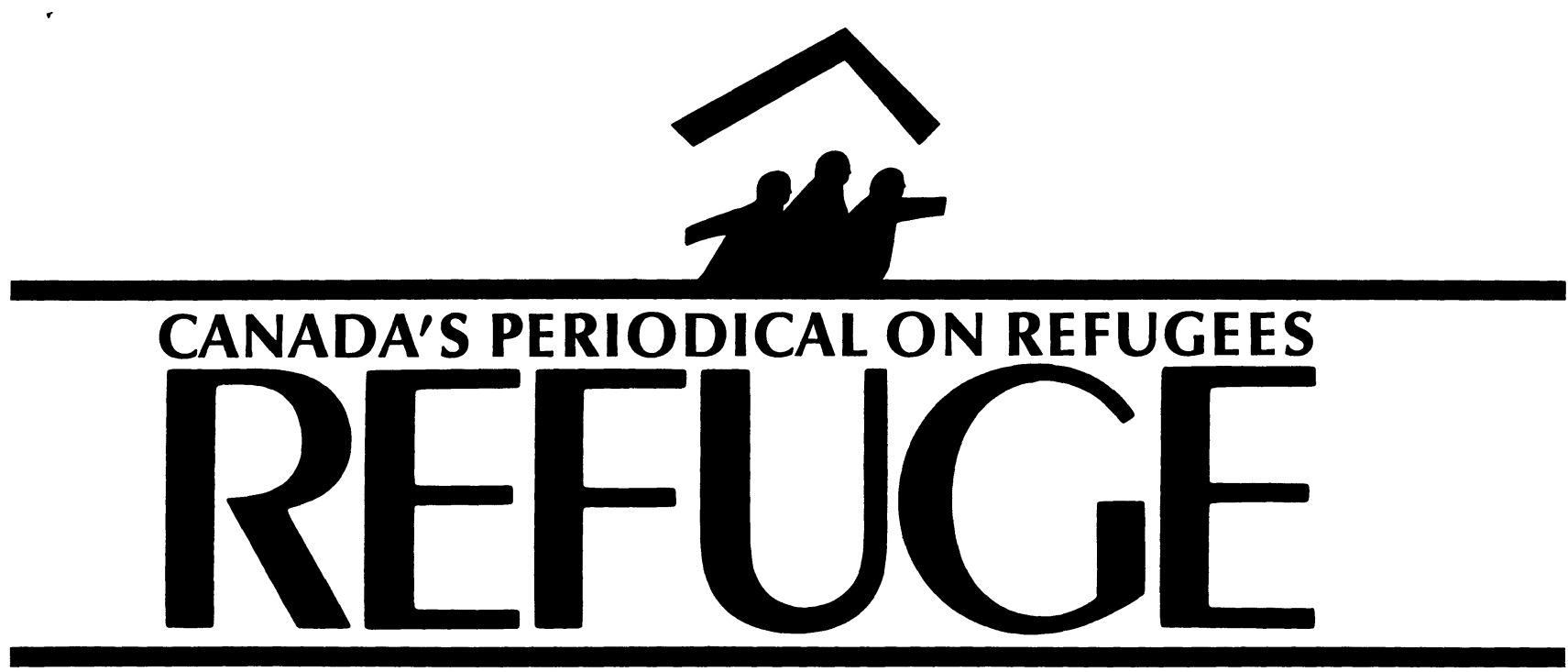

Volume 5, No. 3

January 1986

Betrayal

We thought this would be the last issue in a long time dealing with refugee status determination in Canada. We had written an editorial to that effect. (It is included as an ironic postscript.) Naively, we had expected legislation more or less to follow the essential thrust of the recommendations of a Parliamentary Committee, of the Plaut report, of the religious communities, ethnic groups, humanitarian organizations such as Amnesty International, of academic experts in the field.

Current proposals in preparation for consideration are an insult to Parliament, a travesty of the consultative process, disrespectful of the results of thoughtful and humane consideration, and another formula for embarrassment for the Mulroney government. Refugees have been betrayed. Religious, humanitarian and ethnic leaders have been duped. Rabbi Plaut has been misused. And the considerations and fundamental conclusions of a Parliamentary Committee with a majority of Tories have been rejected.

Instead of the long overdue final move toward a more rational and humane refugee status determination process, humane because it accurately identifies legitimate claimants and does not allow them to languish in limbo, and rational because it effectively puts a stop to large numbers of illegitimate claimants abusing the refugee status determination process, what has been proposed is the castration of any system, however rational and humane it might be.
Restrictive legislation would be introduced to prevent refugee claims from being presented. And the power to make the decisions would be in the hands of adjudicators, not a central authority as recommended by international guidelines and all concerned non-government organizations on this issue. Within 72 hours, the adjudicator could have sent the refugee claimant flying (literally) because, for example, he or she was a Baha'i from Iran who happened to have come here by way of Germany.

The proposals separate the admissibility issue from the merits of any claim. Instead of universal access, there would be limited access. For example, access could be restricted by insisting that, in order to be eligible to make a claim, a refugee must not have come via another country where the refugee could have claimed refugee status.

No due process. Supreme Court Justice Bertha Wilson has written that everyone present in Canada was entitled to the consideration of a judicial process in such situations. But the proposals would have adjudicators at the airport make the decisions. Whatever safeguards are proposed, decisions made within 72 hours will almost never satisfy principles of fairness. The proposals snub the conclusions of the highest court in the land. It is as if the Supreme Court had not ruled that refugee claimants must be offered the protection of the Canadian Charter of Rights. Hawke's Parliamentary Committee need not have seconded Plaut and recommended universal access.

The Minister of Employment and Immigration, Flora MacDonald, at the last meeting of organizations concerned with refugees said that she had some reservations about universal access. But she claimed she had listened to the arguments of those concerned. The fact is that a consultative process is abused when the discussions proceed on one track with a variety of alternatives and, at the last minute, a radically different procedure Continued...

\section{IN THIS ISSUE:}

Report of the Standing Committee on Labour, Employment and Immigration

Dissenting Statement on the Report by Dan Heap

page 3

The Refugee Determination Procedure:

A Growing Concern by Tom Clark

page 7

Racism in Canadian Immigration Policy,

Part Two by David Matas

page 8

page 10 
Continued from page 1

is proposed which separates the question of who is admissible from the procedure itself. In any case, the proposals indicate fundamental opposition to the principle of access and not just reservations.

The proposals probably will be found contrary to law by the Supreme Court if passed as legislation, possibly will be defeated if introduced to Parliament, but more likely will be withdrawn for consideration if Cabinet is foolish enough to buy this disastrous package and send it on to Parliament. Then the long overdue reforms will be delayed another year. The backlog will become much larger. More people will use the refugee claims

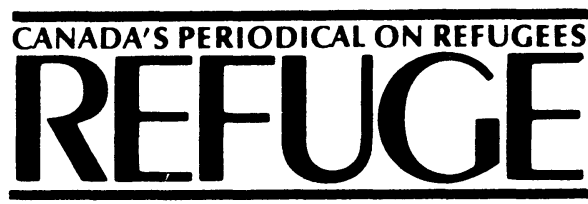

c/o Refugee Documentation Project, York University 4700 Keele Street, North York, Ontario M3J 1P3

\section{Editor: \\ Howard Adelman}

Feature Editor:

Alex Zisman

\section{Managing Editor: \\ Leslie Rider}

Refuge is dedicated to encouraging assistance to refugees, by providing a forum for sharing information and opinion on Canadian and international issues pertaining to refugees. It is published four times a year by the Refugee Documentation Project. It is a non-profit, independent periodical supported by private donations and by subscriptions. It is a forum for discussion, and the views expressed do not necessarily reflect those of its funders or staff.

All material in Refuge may be reproduced without permission unless copyrighted or otherwise indicated. Credit should be given to the author or source if named.

Subscription rates for one year are $\$ 20.00$. Please enclose payment with your order. No discounts can be given for American funds because of bank charges for foreign cheques.

\section{Logo design:}

Dreadnaught Cooperative Inc., Toronto

Second Class Mail Registration No. 5512 ISSN 0229-5113 process as a rear entry point for immigration to Canada. And legitimate refugees will continue to be kept insecurely waiting year after year unable to continue their careers and education.

Access! The central issue is access. The best and most humane process in the world is useless to refugees who arrive at our doorstep only to be sent away as ineligible even to obtain a proper hearing.

Should an individual who arrives on Canadian soil and claims refugee status be entitled to a fair hearing? The Supreme Court said yes. Rabbi Plaut said yes. The Tory dominated Parliamentary Committee said yes. The religious community, ethnic groups and the Nobel prize winning Amnesty International have all said yes. A few civil servants have decided that all of these groups are wrong and they are right.

This misguided group has decided that Canada does not want Europeans and Americans to dump "their" (not our or the world's) refugee problems into Canada. Keep the hordes out. The fact that we are talking about only 2000 or 3000 people per year who are in peril is forgotten.

The issue is no longer about creating a system that will be fair to refugee claimants while discouraging abuse. The issue has become one of restricting access even to legitimate refugees and insisting that they are some other government's problem and not ours.

Concerned Canadians must let our Minister know that such proposals are a betrayal of humanitarian principles and the Canadian Charter of Rights. They are also an abuse of the term consultation. No one asks the government to do everything requested of it. They do ask that as part of the courtesy and dialogue of a consultation that all the alternatives be put on the table for consideration and debate. When a proposal emerges that runs so contrary to the general thrust at the last minute after the consultative process is over, the democratic process has been sabotaged. The Mulroney government does not need another pratfall. It should back the recommendations of its own Parliamentary Committee. Canadians (others are welcome as well) should wire or write the Prime Minister, the Minister of Employment and Immigration, their M.P. and tell them so.

Howard Adelman
James Hathaway
Michael Lanphier

\section{Ironic Postcript}

Status determination in Canada! For the past three years it has dominated, indeed sometimes it has overwhelmed, other critical issues of refugee policy in Canada. We appear to be coming to the end of a long road. New legislation should be forthcoming from Ottawa.

This issue makes clear that we have, in fact, not reached the end of the discussion, only a new plateau from which to view it. Although much fairer procedures may be introduced, there are still claims for higher standards of fairness - a satisfactory system of appeals, looser visa requirements and a better distribution of administrative offices for processing applicants. Even the improved measures proposed do not adequately satisfy the requirements of fairness and the rights of refugees according to the critics.

The debate continues not simply because of a few outstanding issues. The roots go deeper. There is a conflict between a conception of Canada as primarily a state with absolute control over the rights of non-citizens who wish to enter Canada and a conception of Canada as a state with a primary obligation to non-citizens in need who can appeal to Canadian law for protection. Canada's signing of the Refugee Convention already qualified our absolute control over entry. The Charter of Rights and the recent ruling of the $\mathrm{Su}$ preme Court (the Singh case) have extended the protection of our laws to noncitizens on Canadian soil.

We are no longer absolutely sovereign in controlling entry, and once entry is obtained it is clear that anyone on Canadian soil has the right to protection of Canada's laws. Our sovereignty is qualified by our international obligations, our humanitarian concerns and our own domestic legislation.

The ensuing years will witness the extent to which that sovereignty should be qualified in order to be just to non-citizens in need who claim Canadian protection.

H.A. 